\title{
Impact of Audit Committee Characteristics on Dividend Yield of Jordanian Listed Financial Companies
}

\author{
Dr. M. Prabhu ${ }^{1}$ \\ ${ }^{1}$ Assistant Professor, JSS College for Women, JSS Research Foundation, Kollegal, \\ Karnataka, India
}

Omar Hani Mamdouh Alomari ${ }^{2}$

${ }^{2}$ Jordan

Contact Author: omar.alomare88@gmail.com

Dr. Nofan Hamed Al-Olimat

${ }^{3}$ Associate Professor, Al al-Bayt University, Jordan

Contact Author: nofanjo@aabu.edu.jo

\begin{abstract}
The Audit Committee is responsible for overseeing the Board's corporate governance and oversight obligations, including the company's risk management system, internal control system, financial reporting, and internal and external audit tasks. The impact of Audit Committee features on Dividend Policy in financial companies listed on the Amman Stock Exchange was investigated in this study. Dividend Yield per Share was taken into account as part of Dividend Policy in the study, which was based on Jordanian financial enterprises' public financial reports. Multiple regression analysis was employed to examine the impact of AuditCommittee characteristics on DividendYield in Jordanian companies. The results indicated that AuditCommittee characteristics showed a significant effect on DividendYield per Share.
\end{abstract}

Keywords: Audit Committee, Audit Committee Characteristics, Dividend Yield and Financial Companies

\section{Introduction}

Audit Committees are crucial in the context of Corporate Governance because they help the Board of Directors achieve their financial and fiduciary responsibilities to shareholders. Through their Audit Committees, boards of directors establish a direct line of communication with internals, external auditors, and the Chief Financial Officer. The complete Board of Directors can fulfil its goals and policies with such an organisational structure and reporting duty in an atmosphere of open and unfettered access. Companies must have independent audit committees to review and enhance the quality of financial reporting provided by management. 
Jordan, although being a developing country, has a well-organized financial sector, the Amman Stock Exchange (ASE), which has 179 companies listed in 2019. From a financial, regulatory, and legislative standpoint, this market was founded in 1979 and has evolved over the subsequent three decades. In 1999, Jordanian company legislation and Securities Exchange Commission (SEC) regulations established a corporate governance framework, with the creation of Audit Committees at its foundation. In Jordan, audit committees became required for corporations filing with the Jordan Securities Commission in 1998. (JSC). As a result, all publicly traded businesses are required to establish Audit Committees, which enable the Board of Directors to not only get assurance regarding financial reporting and audit processes, but also to approve significant accounting policy decisions like dividend yield and payment policy.

The term "dividend policy" refers to the management's policy or rules for declaring dividends. The percentage of dividends and retained earnings is determined by a dividend policy. Dividends deplete the company's cash reserves, whereas retained earnings are a crucial source of internal funding for long-term growth. "The eventual distribution of the company's earnings between retention (i.e. reinvestment) and cash dividend payments to shareholders is determined by dividend policy."

\section{Review of Literature}

Al-Amarneh\&Yaseen (2014) in the article titled "Corporate Governance and Dividend Policy in Jordan" investigated the relationship using a sample of 47 industrial companies listed on the Amman Stock Exchange (ASE) from 2005 to 2011, researchers looked at the association between corporate governance and dividend policy in Jordan. The findings revealed that large corporations with a strong investment opportunity set (growth) and a high return on equity pay out large dividends, while companies with a high financial leverage degree pay out smaller dividends. The association between corporate governance parameters (company holdings, financial institution holdings, insider holdings, and foreign holdings) and dividend yield was investigated using random regression.Corporate and financial institution holdings had a non-linear relationship with dividend yields, as dividend yields increased up to a certain level as holdings increased, supporting the free cash flow theory, while dividend yields decreased as insiders and foreign holdings increased, supporting the signalling theory.

Alkurdi, Tahat \& Al-mawali (2017) carried out research on the title "The Effect of Governance Attributes on Corporate Dividend Payouts Policy: Evidence from Jordan" investigated the impact of some Corporate Governance (CG) variables on corporate dividend payouts, including board size, independence, separation, and managerial ownership, using a sample of 72 Jordanian listed businesses from 2007 to 2013. The findings show that the CG characteristics studied have a significant impact on corporate dividend decisions. The board size, independence, and separation factors, in particular, all had significant relationships with dividend payouts, demonstrating that the composition of the CG matters when determining dividends, which may assist to avoid conflicts between stockholders' and managers' interests. The results indicated that company size and profitability had statistically positive associations with dividend payouts, while this was not the case for companyleverage and growth. 
Armaya'u\&Awaisu (2017) in the study "Corporate Board Attributes and Dividend Payout Policy of Listed Deposit Money Banks in Nigeria" examined the impact of corporate board qualities on the dividend policy of Nigeria's publicly traded deposit money institutions. The information was gathered from the sampled companies' annual reports and accounts over a fifteen-year period, from 2006 to 2015. Descriptive statistics, correlation analysis, and the panel data regression technique are used to analyse the data. Board size, board composition, audit committee size, and managerial ownership are among the characteristics examined.According to the findings, board size, composition, and ownership structure have a significant negative impact on the dividend policy of listed DMBs in Nigeria, while the audit committee has a statistically minor impact. The report recommended that regulatory bodies increase corporate governance mechanisms, particularly the audit committee's power.

Jaara, Alashhab \& Jaara, O. (2018)in the study entitled "The Determinants of Dividend Policy for Non-Financial Companies in Jordan" investigated the determinants of dividend policy for a sample of Jordanian non-financial enterprises from 2005 to 2016. The focus of this research was on some of the factors that influence the dividend pay-out ratio and dividend yield, including company size, risk, investment prospects, historical dividend, profitability, and leverage. The size of the company had a considerable beneficial impact on free cash flow, with mature and large enterprises paying greater and consistent dividends. The return on equity was positive and considerable, indicating that companies with high profitability were consistently paying greater dividends. Historical dividends had always had a positive and significant influence, indicating a tendency of dividend payout rather than random payments. The payout amounts were found to be negatively impacted by risk.

\section{Objectives of the Study}

- To identify the Audit Committee characteristics influencing Dividend Policy of Jordanian listed Companies.

- To examine the impact of audit committee characteristics on dividend yield of Jordanian listed companies.

\section{Hypothesis of the Study:}

H01:There is a significant relationship between Audit Committee Characteristics and Dividend Yield.

H1.1: There is a significant relationship between Audit Committee Characteristics and Dividend Yield in Jordanian listed financial companies.

\section{Research Methodology}

The research aimed to conduct an empirical study on the factors impacting decisions of dividend policy in the emerging Jordanian market considering a long period. The research sample accordingly consists of a panel dataset of 179 Jordanian companies listed on the 
Amman Stock Exchange over nine years of 2011-2019. The data was collected from Annual Reports published by selected companies listed on the Amman Stock Exchange. From the previous research reviews on audit committee characteristics, this study identified important characteristics that influenced the audit committees in Jordan. The characteristics are Audit Committee Size (ACS), Audit Committee Meetings (ACM), Audit Committee Independence (ACI), Audit Committee Expertise (ACE), and Audit Committee Chairperson (ACC), the impact of which on dividend yield is assessed.

\section{Variables and Models}

\section{Variable Descriptions}

The research consists of two variables - Dependent and Independent variables. Audit Committee and its characteristics is chosen as the Independent variable. The main characteristics are Size, Meetings, Independence, Expertise and Chairperson. Also, variable to proxy for the dependent variable employed is Dividend Yield.

\section{Data Analysis and Interpretation}

\section{Financial Companies only:}

Table 1: Analysis of Results of correlation between ACC and Dividend Yield for Jordanian listed Financial Companies

\begin{tabular}{|c|c|c|}
\hline \multicolumn{2}{|c|}{ Correlation between AC Characteristics and DYPS } & DYPS \\
\hline \multirow{4}{*}{ Audit Committee size } & Pearson Correlation & $\mathbf{0 . 1 0 1}$ \\
\cline { 2 - 3 } & Sig. (2-tailed) & 0.003 \\
\cline { 2 - 3 } Audit Committee expertise & $\mathrm{N}$ & $\mathbf{8 6 4}$ \\
\cline { 2 - 3 } & Pearson Correlation & $\mathbf{0 . 1 1 1}$ \\
\cline { 2 - 3 } & Sig. (2-tailed) & 0.001 \\
\hline \multirow{3}{*}{$\begin{array}{c}\text { Audit Committee } \\
\text { independence }\end{array}$} & N & 864 \\
\cline { 2 - 3 } & Pearson Correlation & $\mathbf{0 . 1 2 8}$ \\
\cline { 2 - 3 } & Sig. (2-tailed) & 0.00 \\
\hline \multirow{3}{*}{\begin{tabular}{c} 
Audit Committee meetings \\
\cline { 2 - 3 }
\end{tabular}} & N & 864 \\
\cline { 2 - 3 } & Pearson Correlation & $\mathbf{0 . 0 9 2}$ \\
\hline \multirow{3}{*}{ AC-Chairperson } & Sig. (2-tailed) & 0.007 \\
\cline { 2 - 3 } & N & 864 \\
\cline { 2 - 3 } & Sig. (2-tailed) & 0.00 \\
\hline
\end{tabular}


The table 1 contains the results of the correlation coefficient for the selected indicators, i.e., Audit Committee Characteristics, Dividend Yield Ratio and its p-value in financial companies only. The Pearson correlation coefficient for Audit Committee size and Dividend Yield is 0.101 with a p-value of 0.003 which is statistically significant as the p-value is lesser than 0.05. The estimated Pearson correlation coefficient for Audit Committee expertise and Dividend Yield is 0.111 with a p-value of 0.001 which is statistically significant as the pvalue is lesser than 0.05. The correlation coefficient for Audit Committee independence and Dividend Yield is 0.128 with a p-value of 0.000 which is statistically significant as the pvalue is lesser than 0.05. The Pearson correlation coefficient for Audit Committee meetings and Dividend Yield is 0.92 with a p-value of 0.007 which is statistically significant as the pvalue is lesser than 0.05. The estimated Pearson correlation coefficient for Audit Committee meetings and Dividend Yield is 0.125 with a p-value of 0.000 which is statistically significant as the p-value is lesser than 0.05. The results of correlation showed that Audit Committee Characteristics and Dividend Yield showed a statistical significance meaning that the factors positively influenced the dividend policy of the company. It also implies that when dividend yield per share increases, the audit committee size, audit committee expertise, audit committee independence, audit committee meeting, audit committee chairperson also rise moderately and vice versa.

\section{Testing of Hypothesis}

\section{Hypothesis 1:}

$\mathrm{H}_{01}$ : There is no significant relationship between Audit Committee Characteristics and Dividend Yield.

$\mathrm{H}_{1}$ : There is a significant relationship between Audit Committee Characteristics and Dividend Yield.

\section{Regression between Dividend Yield Per Share and Audit Committee Characteristics}

Table 3(a): Analysis of Regression Results between Dividend Yield Per Share and Audit Committee Characteristics

\begin{tabular}{|c|c|c|c|c|c|}
\hline Model & $\mathrm{R}$ & $\mathrm{R}$ Square & $\begin{array}{c}\text { Adjusted R } \\
\text { Square }\end{array}$ & $\begin{array}{c}\text { Std. Error of } \\
\text { the Estimate }\end{array}$ & Durbin-Watson \\
\hline 1 & $.299^{\mathrm{a}}$ & .090 & .087 & 3.28 & 1.722 \\
\hline
\end{tabular}

a. Predictors: (Constant), Audit Committee chairperson, Audit Committee Meeting, Audit Committee size, Audit Committee expertise, Audit Committee independence

b. Dependent Variable: DYPS

Source: Output from SPSS

The table 3(a) shows the result of regression between the dependent variable, Dividend Yield Ratio, and independent variables, Audit Committee Expertise, Audit Committee Independence, Audit Committee Size, Audit Committee Meetings, and Audit Committee Chairperson. The R-value of Dividend Yield Ratio and Audit Committee Characteristics is 0.299 . The value of $R^{2}$, which is a measure of how much of the variability in the outcome is 
accounted for by the predictors, is 0.090 , which means that Audit Committee characteristics account for $0.9 \%$ of the variation in the Dividend Yield Ratio.The Durbin-Watson statistic obtained was 1.722 which showed a positive auto-correlation.

Table 3(b): Analysis of Results of ANOVA

\begin{tabular}{|l|c|c|c|c|c|c|}
\hline \multicolumn{2}{|l|}{ Model } & $\begin{array}{c}\text { Sum of } \\
\text { Squares }\end{array}$ & df & Mean Square & F & Sig. \\
\hline \multirow{3}{*}{1} & Regression & 1704.417 & 5 & 340.883 & 31.606 & $.000^{\mathrm{b}}$ \\
\cline { 2 - 7 } & Residual & 17310.466 & 1605 & 10.785 & & \\
\cline { 2 - 8 } & Total & 19014.883 & 1610 & & & \\
\hline
\end{tabular}

a. Dependent Variable: DYPS

b. Predictors: (Constant), Audit Committee chairperson, Audit Committee Meeting,

Audit Committee size, Audit Committee expertise, Audit Committee independence Source: Output from SPSS

The table 3(b) shows the output of the ANOVA analysis. The F-ratio is 31.606 with $p<.001$, i.e., the significance value for Dividend Yield Ratio and Audit Committee Characteristics is 0.000 , which is below 0.05 . The results support the alternative hypothesis that "there is a significant relationship between Audit Committee Characteristics and Dividend Yield Ratio in Jordanian listed companies". It is found that these results imply that Audit Committee Characteristics significantly improve the ability to predict the Dividend Yield Ratio of the selected companies.

Table 3(c): Analysis of Coefficients

\begin{tabular}{|c|c|c|c|c|c|}
\hline \multirow{2}{*}{ Model } & \multicolumn{2}{|c|}{$\begin{array}{c}\text { Unstandardized } \\
\text { Coefficients }\end{array}$} & $\begin{array}{c}\text { Standardized } \\
\text { Coefficients }\end{array}$ & $\mathrm{t}$ & Sig. \\
\cline { 2 - 6 } & B & $\begin{array}{c}\text { Std. } \\
\text { Error }\end{array}$ & Beta & & \\
\hline (Constant) & 0.999 & 0.138 & - & 7.244 & 0.000 \\
\hline Audit Committee Expertise & 1.966 & 0.294 & 0.274 & 6.693 & 0.000 \\
\hline Audit Committee Independence & 0.719 & 0.337 & 0.104 & 2.135 & 0.033 \\
\hline Audit Committee Size & -0.303 & 0.079 & -0.144 & -3.856 & 0.000 \\
\hline Audit Committee Meetings & 0.061 & 0.032 & 0.054 & 1.878 & 0.061 \\
\hline Audit Committee Chairperson & 0.103 & 0.347 & 0.015 & 0.297 & 0.767 \\
\hline
\end{tabular}

a. Dependent Variable: DYPS

The table 3(c) shows the regression coefficients of Audit Committee Characteristics. The regression coefficient of Audit Committee Expertise is 1.966 which indicates a positive effect of Audit Committee Expertise on Dividend Yield Ratio which is statistically significant as the significance value is lesser than 0.05 (5\%). The Audit Committee Expertise and Dividend Yield Ratio have a positive association.The regression coefficient of Audit Committee Independence is.719, indicating that Audit Committee Independence has a positive effect on Dividend Yield Ratio that is statistically significant because the significance value is smaller 
than 0.05 (5 percent). The Audit Committee Independence and Dividend Yield Ratio have a positive association.Because the significance value is less than 0.05 , the regression coefficient of Audit Committee Size is statistically significant (5 percent). The regression coefficient of Audit Committee Meetings is 0.061, indicating a positive influence of Audit Committee Meetings on Dividend Yield Ratio. However, because the significance value is greater than 0.05 , this effect is statistically insignificant (5 percent). The association between Audit Committee Meetings and Dividend Yield Ratio is negligible. The Audit Committee Chairperson's regression coefficient is.103, indicating that the Audit Committee Chairperson has a positive effect on the Dividend Yield Ratio, which is statistically insignificant because the significance value is greater than 0.05 (5 percent). The Audit Committee Chairperson and the Dividend Yield Ratio have a negligible association. As a result, audit committee qualities such as experience, independence, and size, p.01, indicating that Dividend Yield Ratio and audit committee features are related which is in line with the study conducted by Silva, L., et al. (2004), Ghosh \&Sirmans (2006) and Jabbouri, et al., (2014).

Moreover, the table shows the regression coefficients, the intercept, and the significance of all coefficients and the intercept in the model. It is found that linear regression analysis estimates the linear regression function to be

DYPSR $=(.999)+(1.966)$ Audit Committee expertise $+(.719)$ Audit Committee independence $+(-.303)$ Audit Committee size $+(0.061)$ Audit Committee Meeting $+(.103)$ Audit Committee chairperson.

\section{Testing of Sub Hypotheses}

H01.1: There is no significant relationship between Audit Committee Characteristics and Dividend Yield in Jordanian listed financial companies.

H1.1: There is a significant relationship between Audit Committee Characteristics and Dividend Yield in Jordanian listed financial companies.

Table 3(d): Analysis of Regression Results of Audit Committee Characteristics and Dividend Yield Ratio in Financial Companies

\begin{tabular}{|c|c|c|c|c|}
\hline Model & $\mathrm{R}$ & $\mathrm{R}$ Square & $\begin{array}{c}\text { Adjusted R } \\
\text { Square }\end{array}$ & $\begin{array}{c}\text { Std. Error of the } \\
\text { Estimate }\end{array}$ \\
\hline 1 & 0.376 & .141 & .136 & 3.238 \\
\hline
\end{tabular}

a. Dependent Variable: Dividend Yield Ratio

b. Predictors: (Constant), Audit Committee Expertise, Audit Committee Independence, Audit Committee Size, Audit Committee Meetings, and Audit Committee Chairperson

Source: Output from SPSS.

The table 3(d) shows the result of regression between the dependent variable, Dividend Yield Ratio, and independent variables, Audit Committee Characteristics such as Audit Committee Expertise, Audit Committee Independence, Audit Committee Size, Audit Committee Meetings, and Audit Committee Chairperson. R Square for Dividend Yield Ratio and Audit 
Committee Characteristics is 0.141 indicating the variation in Dividend Yield Ratio which is explained by the Audit Committee Characteristics to the extent of $14.1 \%$.

Table 3(e): Analysis of Results of ANOVA

\begin{tabular}{|l|c|c|r|r|r|r|}
\hline \multicolumn{2}{|c|}{ Model } & $\begin{array}{c}\text { Sum of } \\
\text { Squares }\end{array}$ & df & $\begin{array}{c}\text { Mean } \\
\text { Square }\end{array}$ & F & Sig. \\
\hline \multirow{3}{*}{1} & Regression & 1478.955 & 5 & 295.791 & 28.208 & .000 \\
\cline { 2 - 8 } & Residual & 8997.188 & 858 & 10.486 & & \\
\cline { 2 - 8 } & Total & 10476.142 & 863 & & & \\
\hline
\end{tabular}

a. Dependent Variable: Dividend Yield Ratio

b. Predictors: (Constant), Audit Committee Expertise, Audit Committee Independence, Audit Committee Size, Audit Committee Meetings, and Audit Committee Chairperson

Source: Output from SPSS.

The table 3(e) shows the output of the ANOVA analysis. The F value is 28.208 and the significance value for Dividend Yield Ratio and Audit Committee Characteristics is 0.000 (i.e., $\mathrm{p}=.000$ ), which is below 0.05 indicating there is a statistically significant relationship between Dividend Yield Ratio and Audit Committee Characteristics for Jordanian listed financial companies. The results support the alternative hypothesis that "there is a significant relationship between Audit Committee Characteristics and Dividend Yield Ratio in Jordanian listed financial companies".

Table 3(f): Analysis of Coefficients

\begin{tabular}{|c|c|c|c|c|c|}
\hline \multirow{2}{*}{ Model } & \multicolumn{2}{|c|}{$\begin{array}{c}\text { Unstandardized } \\
\text { Coefficients }\end{array}$} & $\begin{array}{c}\text { Standardized } \\
\text { Coefficients }\end{array}$ & $\mathrm{t}$ & Sig. \\
\hline B & $\begin{array}{c}\text { Std. } \\
\text { Error }\end{array}$ & Beta & & \\
\hline (Constant) & .486 & .179 & & 2.710 & .007 \\
\hline Audit Committee Expertise & 2.325 & .230 & .325 & 10.097 & .000 \\
\hline $\begin{array}{c}\text { Audit Committee } \\
\text { Independence }\end{array}$ & 2.496 & .223 & .357 & 11.216 & .000 \\
\hline $\begin{array}{c}\text { Audit Committee Size } \\
\text { Audit Committee Meetings }\end{array}$ & .661 & .065 & .326 & 10.122 & .000 \\
\hline Audit Committee Chairperson & 2.395 & .223 & .343 & 10.732 & .000 \\
\hline
\end{tabular}

a. Dependent Variable: Dividend Yield Ratio

b. Predictors: (Constant), Audit Committee Expertise, Audit Committee Independence, Audit Committee Size, Audit Committee Meetings, and Audit Committee Chairperson

Source: Output from SPSS. 
The table 3(f) shows the regression coefficients of Audit Committee Characteristics. The Audit Committee Expertise regression coefficient is 2.325, indicating a positive influence of Audit Committee Expertise on Dividend Yield Ratio, which is statistically significant because the significance value is smaller than 0.05 ( 5 percent). The Audit Committee Expertise and Dividend Yield Ratio have a positive association.The Audit Committee Independence regression coefficient is 2.496, indicating that Audit Committee Independence has a positive effect on Dividend Yield Ratio, which is statistically significant because the significance value is smaller than 0.05 (5 percent). The Audit Committee Independence and Dividend Yield Ratio have a positive association.The regression coefficient of Audit Committee Size is.661, indicating that Audit Committee Size has a positive effect on Dividend Yield Ratio that is statistically significant because the significance value is smaller than 0.05 (5 percent). The size of the audit committee and the dividend yield ratio have a favourable association.Audit Committee Meetings has a regression coefficient of.317, indicating a positive effect of Audit Committee Meetings on Dividend Yield Ratio, which is statistically significant because the significance value is less than 0.05 (5 percent). Audit Committee Meetings and Dividend Yield Ratio have a favourable association.The Audit Committee Chairperson's regression coefficient is 2.395, indicating that the Audit Committee Chairperson has a positive effect on the Dividend Yield Ratio, which is statistically significant because the significance value is smaller than 0.05 (5 percent). The Audit Committee Chairperson and the Dividend Yield Ratio have a positive association.

\section{Conclusion}

This study examined the impact of audit committee characteristics on dividend yield in the financial companies listed on Amman Stock Exchange. The data related to audit committees' impact was collected through a secondary sources of data such as company websites, annual reports of companies and stock exchange reports and circulars. Dividend yield per share was taken into account as part of the dividend policy in the analysis, which was based on Jordanian financial enterprises' public financial reports. The impact of audit committee features on dividend yield in Jordanian companies was investigated using multiple regression analysis. The findings revealed that the audit committee's composition had a considerable impact on dividend yield per share. The dividend policy choice is deciding whether to distribute earnings to stockholders or to keep them for reinvestment in the business. The best dividend policy for the business is one that strikes a balance between present dividends and future growth.

\section{References:}

- Armaya'uAlhaji Sani et al. (2017), Corporate Board Attributes and Dividend Payout Policy of Listed Deposit Money Banks in Nigeria, International Journal of Research in IT, Management and Engineering, ISSN 2249-1619, Impact Factor: 6.123, Volume 07 Issue 1, January 2017, Pages 7-13. 
- Al-Amarneh, A., \&Yaseen, H. (2014), Corporate governance and Dividend Policy in Jordan, International Journal of Economics and Finance, 6(4), 210, Auditing, 23(1), 69-87.

- Alkurdi, A., Tahat, Y., \& Al-mawali, H. (2017), The Effect of Governance Attributes on Corporate Dividend Payouts Policy: Evidence from Jordan. International Journal of Corporate Governance, 8(3-4), 313-334

- Jaara, B., Alashhab, H., \&Jaara, O.O. (2018), The Determinants of Dividend Policy for Non-Financial Companies in Jordan,International Journal of Economics and Financial Issues, 8(2), 198-209

- Amman Stock Exchange (ASE), https://www.ase.com.jo/en

- Annual Reports of Financial companies (2011-19), Jordan

- Securities Depository Center (SDC), https://www.sdc.com.jo/english/

- https://tradingeconomics.com/jordan/stock-market 